\title{
I solation, purification, characterization and applications of serine protease from Bacillus megaterium
}

\author{
T. S. Rajesh*, Deepa, Divya, M. M ahesh and Somshekar \\ Azyme Biosciences Pvt.Ltd 1188, 26 $6^{\text {th }}$ Main, $9^{\text {th }}$ Block Jayanagar, Bangalore-560 069 (Karnataka), INDIA \\ *Corresponding author. E-mail: srajesht@gmail.com
}

\begin{abstract}
Bacillus megaterium isolated from poultry farm soil was identified by standard biochemical tests and screened for the production of serine protease. Production of serine protease was done using 5 different medias by varying the type of amino acid added. The purification was done by salt precipitation, dialysis and DEAEcellulose ion exchange chromatography. The proline containing media obtained the highest fold purification out of the five different medias (leucine lysine, proline, tryptophan and methionine cotaining media). The enzyme showed an optimal activity at the temperature $37^{\circ} \mathrm{C}$ and the $\mathrm{pH} 6$ which are known as its optimum temperature and $\mathrm{pH}$ respectively. The enzyme was proved as a $\mathrm{Mn}^{2+}$ dependent serine protease as it was activated by $\mathrm{Mn}^{2+}$ ions and inhibited by PMSF. The molecular weight of the enzyme was determined by SDS-PAGE technique as around $30 \mathrm{kDa}$. It showed an excellent detergent activity on the blood stains and a very good stability in presence of locally available detrgents. The enzyme acted on the keratin protein of the chicken feather and showed a degrading capacity on the protein. So it was proved that the recently studied serine protease has a keratinase activity also. From these datas I conclude that the protease isolated from Bacillus megaterium is a $\mathrm{Mn}^{2+}$ dependent serine protease which has both keratinase and detergent activity.
\end{abstract}

Keywords: Bacillus megaterium, Keratinase, serine protease, phenylmethanesulfonylfluoride(PMSF)

\section{INTRODUCTION}

Serine proteases are generally the endopeptidases. These are present in the body of almost all the organisms. As the serine proteases have diverse role in human health; from non-specific digestion to highly regulated functions like embryonic development, immune response and blood coagulation, which require highly regulated and specifically limited proteolysis. So in many members of this family the activity and specificity are allosterically regulated by macromolecular ligands or small cations like $\mathrm{Naz}, \mathrm{Ca}^{2} \mathrm{z}$ (Page and Di Cera, 2006).

Subtilisins are the best-known microbial alkaline serine proteases produced by Bacillus subtilis (Robert, 1975). The high stability and relatively low substrate specificity made them successful for the industrial use. The alkaline proteases are employed primarily as cleansing additives. Among these proteases, the bacterial proteases are most significant, compared with animal and fungal proteases (Ward, 1985). The proteases used in detergent formulation should have a broad range $\mathrm{pH}$ and temperature activities (Kunamneni etal., 2003).

The keratinases have several potential applications as detergent for textile fibers (Bergkvist, 1963), in leather processing (Dayanandan et al., 2003, Riffel et al., 2003), waste chicken feather degradation (Bockle et al.,1997, Cheng et al., 1995, Lin et al.,1996) conversion of waste feather to feather meal for livestock (Onifade et al.,1998), hydrolysis of protein from keratinous waste materials (Kida et al.,1995) etc. These facilitate the procesing keratin containing waste from poultry and feather industries by nonpolluting methods (Onifade et al., 1998). In addition, these proteases are used in production of foodstuffs, leather, pharmaceuticals, diagnostic reagents, waste management, silver recovery, skin care ointments, contact lens cleaners, and for research purposes in synthetic organic chemistry.

In this work, the purification and characterization of an extracellular protease isolated from gram-positive soil bacteria is done. The enzyme is proved as the serine protease by being inhibited specifically by PMSF. The detergent activity and the keratinase activity of the enzyme are also studied.

\section{MATERIALS AND METHODS}

I solation and identification of Bacillus megaterium form poultry farm soil: The soil sample was collected from the Poultry farm wastage area in Madiwala, Bangalore. The micro organisms were isolated from the soil by serial dilution method (Alexander,1965, Jackie Reynolds, 2005). The microorganisms were identified by several biochemical tests and staining techniques.

Screening for the production of enzyme: The micro organisms were screened in the Skim- Milk agar for their 
Table 1. Purification of the enzyme.

\begin{tabular}{|c|c|c|c|c|}
\hline & Protein Content (g) & Activity (U/ml) & $\begin{array}{c}\text { Specific Activity } \\
(U / \mathrm{mg})\end{array}$ & Fold Purified \\
\hline \multicolumn{5}{|l|}{ M edia 1: } \\
\hline Crude & 3.6 & 0.0161 & 0.00447 & 1 \\
\hline After Dialysis & 1.7 & 0.6127 & 0.3604 & 80.63 \\
\hline After Ion Exchange & 0.12 & 0.071 & 0.5917 & 132.4 \\
\hline \multicolumn{5}{|l|}{ M edia 2: } \\
\hline Crude & 3.6 & 0.0161 & 0.00447 & 1 \\
\hline After Dialysis & 1.3 & 0.1953 & 0.1502 & 33.6 \\
\hline After Ion Exchange & 0.6 & 0.162 & 0.27 & 60.4 \\
\hline \multicolumn{5}{|l|}{ M edia 3: } \\
\hline Crude & 2 & 0.0059 & 0.00295 & 1 \\
\hline After Dialysis & 1.8 & 0.2122 & 0.1179 & 37.97 \\
\hline After Ion Exchange & 0.16 & 0.0203 & 0.1269 & 43 \\
\hline \multicolumn{5}{|l|}{ M edia 4: } \\
\hline Crude & 2.6 & 0.0176 & 0.00677 & 1 \\
\hline After Dialysis & 1.14 & 0.1145 & 0.1004 & 14.83 \\
\hline After Ion Exchange & 0.16 & 0.0385 & 0.2406 & 35.54 \\
\hline \multicolumn{5}{|l|}{ M edia 5: } \\
\hline Crude & 3 & 0.0264 & 0.0088 & 1 \\
\hline After Dialysis & 1.58 & 0.303 & 0.1918 & 21.8 \\
\hline After Ion Exchange & 0.08 & 0.023 & 0.2875 & 32.7 \\
\hline
\end{tabular}

protease producing ability(Abdelnasser et al., 2007). Production of serine protease: The enzyme was produced from Bacillus megaterium in 5 different medias which differ only in case of the amino acid they possess. Incubated the inoculated medias for 24 hours at $37^{\circ} \mathrm{C}$ in the shaker incubator (Huang Guangrong et al., 2006).

Purification and characterisation of serine protease: The enzyme was extracted from the production media by centrifuging at $4{ }^{\circ} \mathrm{C}$. These crude enzymes were purified by 3 steps, salt precipitation $(80 \%$ saturation with ammonium sulphate), dialysis and finally ion exchange chromatography. The enzyme activity of the crude, dialysed and purified enzyme samples was assayed by a standard assay method using casein as the substrate. Where one unit will hydrolyze casein to produce color equivalent to $1.0 \mu$ mole ( $181 \mathrm{mg}$ ) of tyrosine per minute at pH 7.5 at $37^{\circ} \mathrm{C}$ (Anson, 1938). The protein content was also estimated in each case by Folin- Lowry method and BSA as standard. The optimumactivity of the enzyme was determined by assaying these at different temperatures $\left(4^{\circ} \mathrm{C}, 25^{\circ} \mathrm{C}, 37^{\circ} \mathrm{C}, 65^{\circ} \mathrm{C}\right.$ and $\left.100^{\circ} \mathrm{C}\right)$ and $\mathrm{pH}$ $(2,4,6,8,10)$ (HUANG Guangrong et al., 2006). The type of protease enzyme was determined by assaying them in presence of $\mathrm{mg} / \mathrm{ml}$ of $\mathrm{MnCl}_{2}$ and $\mathrm{mg} / \mathrm{ml}$ of PMSF. The molecular weight of the enzyme was determined by SDSPAGE technique.

A pplications of serine protease: Two applications of the enzyme were studied. The keratinase activity of the enzyme was studied by treating the raw keratin source (chicken feather) at $37^{\circ} \mathrm{C}$ for 12 hours. The detergent activity of the enzyme was also studied by treating it on blood stain along with a local detergent (Surf excel).

\section{RESULTS AND DISCUSSION}

The assay results showed that the proline containing media produced better active protease out of all the five medias. So it is proved that the proline has the most inducible activity among the five amino acids (Table 1). The present study supports the statement of Bjorklind and Arvidson (1978). Proline which was also found to be essential for proteinase synthesis, seems to act in the same way by affecting the intracellular concentrations of glutamic acid, aspartic acid and alanine. Proline was essential for proteinase synthesis in post-exponential growth but not for bacterial growth.

Characterization of serine protease: The effect of temperature on the activity of the purified enzyme was analyzed at $4^{\circ} \mathrm{C}$ to $100^{\circ} \mathrm{C}$. The results showed a bell shaped curve with an optimal activity at $37^{\circ} \mathrm{C}$ The enzyme will be active in a range of $27-55^{\circ} \mathrm{C}$ and the activity will be almost blocked in a higher and lower temperatures (Fig. 1). The results were much similar to Usharani and Muthuraj,2009 where they purified protease from Bacillus laterosporus which is active at $40^{\circ} \mathrm{C}$. The stability was decreased as the temperature was increased from the optimum due to the breakage in the hydrogen bonding. The optimum temperature was slightly higher than from other reporter's results of Aspergillus nidulans (Charles et al., 2008).

Effect of $\mathrm{pH}$ on protease activity: The enzyme activity of the purified enzyme was detected at $\mathrm{pH} 2$ to 10 . The graph showed that the optimum $\mathrm{pH}$ for the enzyme is 6 The 


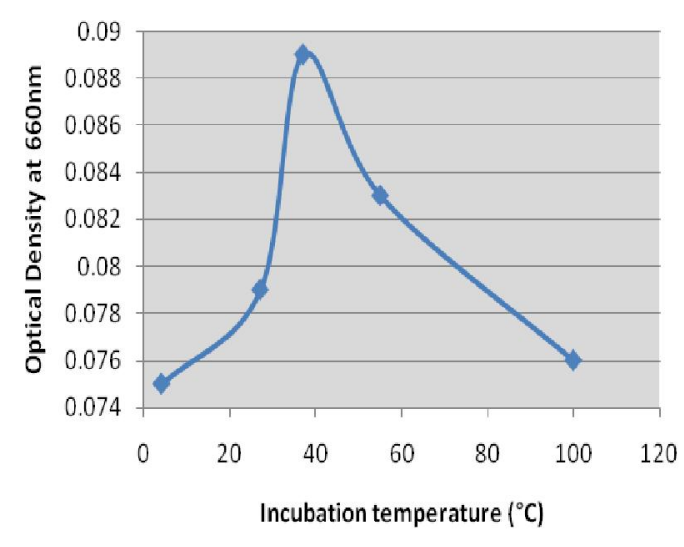

Fig. 1. E ffect of temperature on enzyme activity.

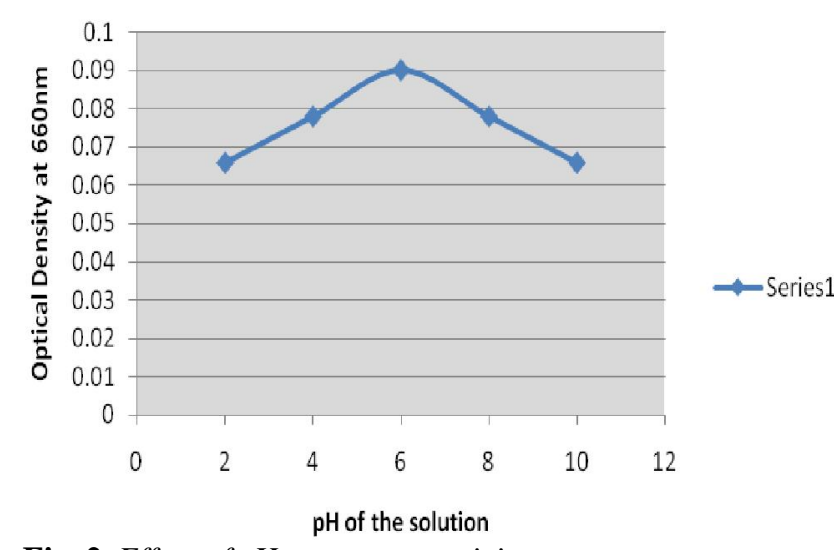

Fig. 2. Effect of pH on enzyme activity.

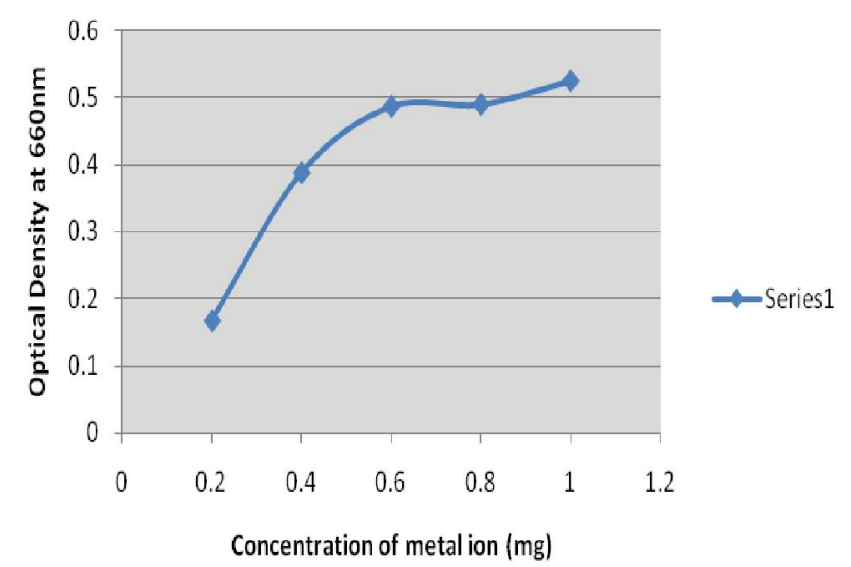

Fig.3. Effect of metal ion on enzyme activity.

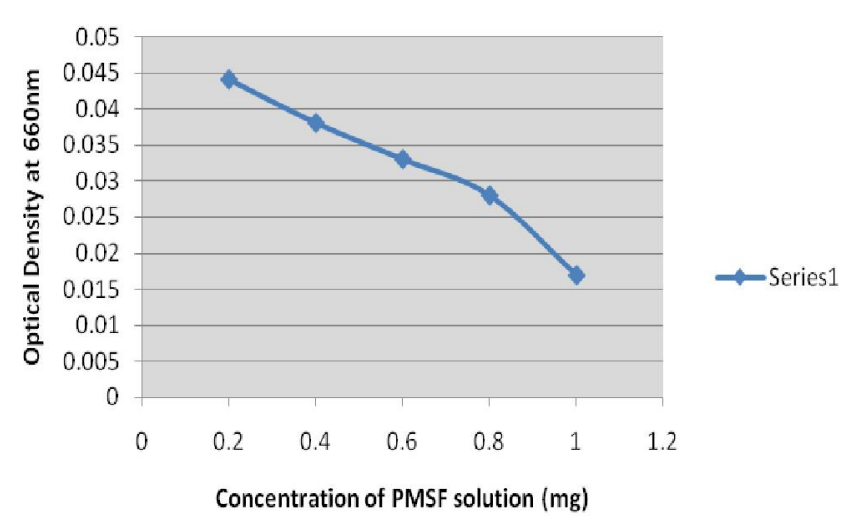

Fig. 4. Effect of PMSF on enzyme activity. enzyme was active in a range of 5-7 (Fig. 2). It is different to Saurabh et al., 2007. In Asokan and Jayanthi, 2010. It was found to be $80^{\circ} \mathrm{C}$ at $9 \mathrm{pH}$. Extremely high or low $\mathrm{pH}$ values generally result in complete loss of activity for most enzymes. $\mathrm{pH}$ is also a factor in the stability of enzymes. As with activity, for each enzyme there is also a region of $\mathrm{pH}$ optimal stability (Bennett andFrieden, 1969).

Effect of $\mathrm{M} \mathrm{n}^{2+}$ and PMSF on protease activity: The investigation on the metal ion activity on serine protease showed that the enzyme activity increased with $\mathrm{Mn}^{2+}$ ions concentrations (Fig. 3). Thus the enzyme has an enhanced activity in presence of $\mathrm{Mn}^{2+}$ ions. Inhibition studies primarily give an insight into the nature of an enzyme, its cofactor requirement and the nature of the active center (Sigma and Mooser,1975). The presence of PMSF inhibited the enzyme activity completely (Fig. 4). These results were similar to those of (Tsuchida et al., 1986, Wang et al., 2006, Yamagata and Ichishima, 1989), the protease was completely inhibited by PMSF. This proved that the enzyme is a $\mathrm{Mn}^{2+}$ dependent serine protease.

SDS-PAGE: The molecular weight of the protease was determined by the SDS PAGE technique by comparing with the migration distances of standard marker protein. A mixture of carbonic anhydrase, egg albumin and BSA was used as the marker, which has the molecular weight of 67,45 and $30 \mathrm{kDa}$ respectively (Kunamneni Adinarayana et al., 2003). Depending on the relative mobility, the molecular weight of the protein was calculated to be around 30kDa (Plate 1.). Generally the molecular weight of the protease comes in a range 15- 30 kDa (Kelly and Fogarty, 1976).

A pplications of serine protease: The serine protease enzyme produced by Bacillus megaterium showed a well characterized keratinase activity. The activity was shown at $37^{\circ} \mathrm{C}$ and a $\mathrm{pH}$ of 7.5 using the sodium phosphate buffer). The feather keratin has been used as the substrate for the keratinase assay in the recent study, as the feather protein has been showed to be an excellent source of the metabolizable protein (Klemersrud et al., 1998) and the microbial keratinases enhance the digestibility of the feather keratin (Lee et al., 1991 and Odetallah et al., 2003).

Besides $\mathrm{pH}$, a good detergent protease is expected to be stable in the presence of commercial detergents. The protease showed an excellent activity when it was used as an additive in detergent (Surf excel). The protease removed the entire bloodstain from the cloth and expressed a very good detergent activity at room temperature. Mohsen, 2005 reported the usefulness of protease from Pseudomonas aeruginosa for removal of blood stains from cotton cloth in the presence and absence of detergent.

Serine Proteases have found a wide range of applications 


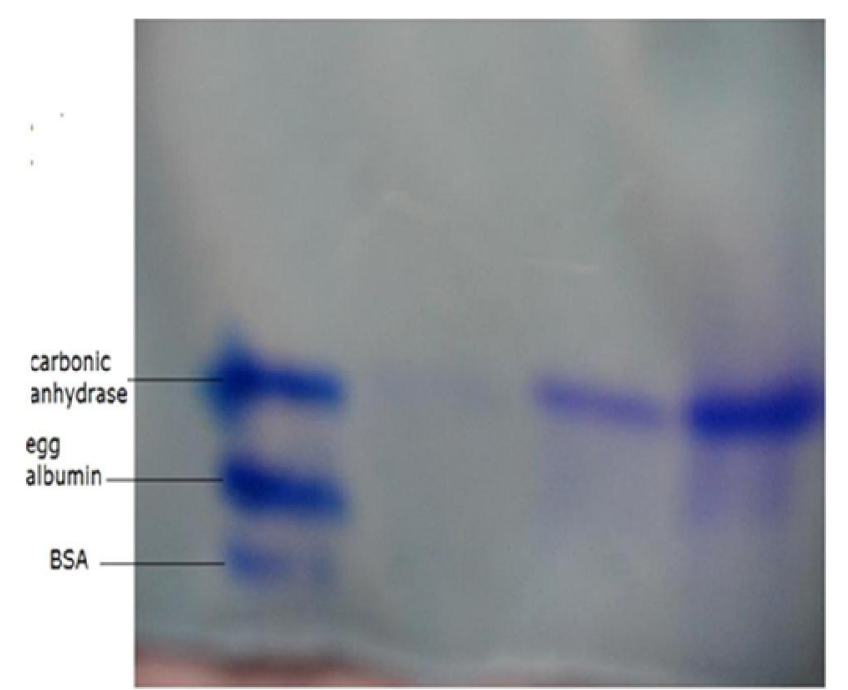

Plate.1. SD S PAGE of the pure enzyme.

in various industries such as food, detergent, pharmaceutical, cosmetic, etc. and have been widely commercialised by various companies throughout the world. Though the production of these enzymes has been improved significantly by the utilisation of hyperproducing strains of fungi and bacteria and genetically modified microbes as well, efforts are still being done to find newer sources of enzymes, better production techniques and novel applications of these enzymes in unexplored fields.

\section{REFERENCES}

Abdelnasser, S. S., Ibrahim, Nefisa M A, EI-Shayeb and Sohair, S. Mabrouk (2007). Isolation and Identification of Alkaline Protease Producing Alkaliphilic Bacteria from an Egyptian Soda Lake. J ournal of Applied Sciences Research. 3(11): 1363-1368.

Anson, M. L. (1938). The estimation of pepsin, trypsin, papain, and cathepsin with hemoglobin Journalernal of Gen. Physiology, 22: 79-89.

Asokan, S. and Jayanthi, C. (2010). Alkaline protease production by Bacillus licheniformis and Bacillus coagulan, J ournal of Cell and Tissue Research, 10 (1):2119-2123.

Bennett, T. P. and Frieden (1969). Modern Topics in Biochemistry, pg. 43-45, Macmillan, London.

Bergkvist, R. (1963). The proteolytic enzymes of Aspergillus oryzae. I. Methods for estimation and isolation of the proteolytic enzymes, Acta Chem. Scand. 17; 1521-1540.

Bjorklind and S. Arvidson (1978). Influence of amino acids on the synthesis of an extracellular proteinase from Staphylococcus aureus. J ournal of General Microbiology, 107: 367-375.

Bockle, B., Galunsky and R. Muller (1995). Characterization of a keratinolytic serine proteinase from Streptomyces pactum DSM 40530. Appl. Environ. and Microbiol., 63: 55-61.

Charles, V. Devanathan, Periasamy Anbu, M. N. Ponnuswamy1, P. T. Kalaichelvan and Byung-Ki Hur (2008). Purification, characterization and crystallization of an extracellular alkaline protease from Aspergillus nidulans HA-
10, J ournal of Basic M icrobiology, 48: 347-352

Cheng, S. W., H. M., Hu, S. W. Shen, H. Takagi, M. Asano and Y. C. Tsai (1995). Production and characterization of keratinase of feather degrading Bacillus licheniformis PWD1, Biosci. Biotech. Biochem, 59;2239-2243.

Dayanandan, A., J. Kanagaraj, L. Soundarray, R. Govindaraju and G. S. Rajkumar (2003). Application of alkaline protease in leather processing: an eco-friendly approach, J . Cleaner Production, 11: 533-536.

Huang Guangrong, Ying Tiejing, Huo Po and Jiang Jiaxing (2006). Purification and characterization of a protease from Thermophilic bacillus strain HS08, African J ournal of Biotechnology, 5 (24): 2433-2438.

Jackie Reynolds (2005). Serial Dilution Protocols, Microbe Library ( ournal of M icrobiology \& Biology Education).

Kelly C.T. and Fogarty W. M.(1976) Microbial alkaline enzymes. Process Biochem., 11:3-9

Kida K, S. Morimura, J. Noda, Y. Nishida, T. Imai and M. Otagiri (1995). Enzymatic hydrolysis of horn and hoof of cow and buffalo. J. Ferment. Bioeng., 80: 478-484.

Kim, J. M., W. J. Lim and S. J. Suh (2001). Feather degrading Bacillus species from poultry waste. Process B iochem., 37: 287- 291.

Klemersrud, M. J., Klopfenstein, T. J. and Lewis, A. J. (1998). Complementary responses between feather meal and poultry by-product meal with or without rumminally protected methionine and lysine growing calves. J . Anim. Sci., 76: 19701975.

Kunamneni Adinarayana, Poluri Ellaiah and Davuluri Siva Prasad (2003). Purification and partial characterization of thermostable serine alkaline protease from a newly isolated B acillus subtilisins PE-11, AAPS PharmSciTech, 4 (4) Article 56.

Lee, C. G., Forket, P. R. and Shih, J. C. H. (1991). Improvement of feather digestibility by bacterial keratinase as a feed additives, FASE B. . .,59:1312.

Lin, X., J. C. H. Shih and H. E. Swaisgood (1996). Hydrolysis of feather keratin by immobilized keratinase. A ppl. Environ. Microbiol., 62: 4273-4275.

Mohsen Fathi Najafi, Dileep Deobagkar and Deepti Deobagkar (2005). Potential application of protease isolated from Pseudomonas aeruginosa PD100. Electronic Journal of Biotechnology, 8:2

Niu Qiuhong, Huang Xiaowei, Tian Baoyu, Yang Jinkui, Liu Jiang, Zhang Lin and Zhang Keqin (2006). Bacillus sp. B16 kills Nematodes with a serine protease identified as a pathologic factor. Appl. M icrobiol Biotechnol., 69: 722-730.

Odetallah, N. H., Wang, J. J., Garlich, J. D. and Shih, J. C. H. (2003). Keratinase in starter diets improves growth of broiler chicks, Poultry Sci., 82: 664- 670.

Onifade, A. A., N. A. Al-Sane, A. A. Al- Musallam and S. Zarban (1998). A review: Potentials for biotechnological applications of keratin-degrading microorganisms and their enzymes for nutritional improvement of feathers and other keratins as livestock feed resources. Bioresource Technol., 66: 1-11.

Page, M. J. and Di Cera, E. (2006). Role of Na and K in enzyme function. Physiol. Rev., 86: 1049-1092.

Riffel, A., F. S. Lucas, P. Heeb and A. Brandelli (2003). Characterization of new keratinolytic bacterium that 
completely degrades native feather keratin. Archives Microbiol., 179: 258-265.

Robert S. Boethling (1975). Purification and properties of serine protease from Pseudomonas maltophilia. J. Bacteriol., 121(3): 933-941.

Saurabh, S., Jasmine, I., Pritesh, G. and Rajendra Kumar, S. (2007). Enhanced productivity of serine alkaline protease by Bacillus sp. using soybean as substrate. Malaysian J ournal of Microbiology, 3(1): 1-6.

Sigma, D. S. and Mooser, G. (1975). Chemical studies of enzyme active sites. Ann. Rev. Biochem., 44: 889-931.

Tsuchida, O., Yamagota, Y., Ishizuka, J., Arai, J., Yamada, J., Takeuchi, M. and Ichishima, E. (1986). An alkaline protease of an alkalophilic Bacillus sp. C urr. M icrobiol., 14:7-12.
Usharani, B. and Muthuraj, M. (2009). Production and characterization of protease enzyme from Bacillus later osporus, G lobal J ournal of M olecular Sciences, 4 (2): 180-186.

Wang, R. B., Yang, J. K., Lin, C., Zhang, Y. and Zhang, K.Q.(2006). Purification and characterization of an extracellular serine protease from the nematode-trapping fungus Dactylella shizishanna, Letters in applied Microbiology, 42: 589-594.

Ward, O. P. (1985). Proteolytic enzymes, In:Blanch HW, Drew S, Wang DI, eds. Comprehensive Biotechnology, 3; 789818 .

Yamagata, Y. and Ichishima, E. (1989). A new alkaline proteinase with PI 2,8 from alkalophilic Bacillus species, Curr. Microbiol., 19: 259-264. 